\title{
Analisa Gempa dalam C050296F untuk Penyelidikan Kecepatan Gelombang S di Bawah Plato Ontong-Jawa
}

\author{
Bagus Jaya Santosa \\ Jurusan Fisika, FMIPA ITS \\ Jl. Arif Rahman Halim 1, Surabaya 60111 \\ bjs@physics.its.ac.id
}

\begin{abstract}
Abstrak. Seismogram gempa bumi dalam C050296F telah dianalisa pada berbagai stasiun di sekitarnya, yaitu HNR, MSVF, CTAO dan SNZO untuk menyelidiki struktur kecepatan gelombang $\mathrm{S}$ di bawah Plato Ontong-Jawa (POJ) di Equator Pasifik Barat. Seismogram sintetik dihitung dengan metoda GEMINI, yang input awalnya adalah model bumi PREMAN, solusi CMT gempa dan koordinat stasiun observasi. Fase-fase gelombang S, Love dan Rayleigh, dan gelombang dalam $\mathrm{ScS}, \mathrm{ScS}_{2}$ dan fase-fase dalam yang dipantulkan oleh permukaan bumi digunakan dalam penelitian ini. Perbandingan seismogram antara seismogram terukur dan sintetiknya menunjukkan diskrepansi yang berbeda-beda untuk beragam arah azimuth dari hiposenter. Di daerah POJ ke tenggara anomali bernilai negatif, sama dengan hasil riset seismologi sebelumnya di daerah yang sama. Ke arah stasiun MSVF daerah POJ memiliki anomali positif, berbeda dengan hasil riset seismologi sebelumnya. Anomali terjadi tidak hanya di mantel atas, tetapi juga pada lapisan-lapisan di bawahnya hingga CMB.
\end{abstract}

Kata kunci: gelombang $S$; perbandingan seismogram; struktur kecepatan gelombang $S$ dari mantel atas hingga $C M B$.

\begin{abstract}
The seismogram of a deep earthquake, C050296F, has been analyzed at various stations around the quake's epicenter, that are HNR, MSVF, CTAO and SNZO, to investigate the S speed structure below the Ontong-Java Plateau (OJP) in Pacific West Equator. The synthetic seismogram is calculated using GEMINI method, whose input consists of PREMAN earth model, the earthquake's CMT solution and coordinates of observation stations. Wave phases namely S, Love and Rayleigh, and depth phases $\mathrm{ScS}, \mathrm{ScS}_{2}$ and by the earth surface reflected depth phases are used in this research. The seismogram comparison between the measured and the synthetic shows various discrepancies in values of each azimuth direction of hypocenter. The OJP to southeast has a negative anomaly, which is the same as the previous seismological results in the same area. Southeast to station MSVF, the area of OJP has a positive anomaly, which is different from the result of previous seismological researches. Anomalies occur not only in upper mantle, but also at layers below it, until CMB.
\end{abstract}

Makalah diterima redaksi tanggal 1 September 2006, revisi diterima tanggal 21 November 2006, diterima untuk diterbitkan tanggal 15 Desember 2006. 
Keywords: seismogram comparison; $S$ wave; $S$ wave velocity structure from the upper mantle down to $C M B$.

\section{$1 \quad$ Pendahuluan}

\subsection{Latar Belakang}

Kami sajikan hasil analisa gelombang $\mathrm{S}$, gelombang dalam $\mathrm{ScS}$ dan $\mathrm{ScS}_{2}$ dan gelombang-gelombang dalam yang dipantulkan oleh permukaan bumi untuk menilai sifat mantel di bawah Plato Ontong-Java (OJP). OJP merupakan dasar laut yang lebih dangkal daripada dasar laut disekitarnya, merupakan provinsi batuan beku bawah laut dan memiliki bentuk L, yang terletak di Pasifik Barat Daya antara Kepulauan Solomon dan ke selatan dan Kepulauan Karolina ke arah utara. OJP mencakup suatu area dengan luas kasar 1,6 × $106 \mathrm{~km}^{2}$. Rata-rata ketinggian dasar laut OJP adalah $2000 \mathrm{~m}$ di atas dasar lautan sekitarnya, dengan kedalaman rata-rata $4000 \mathrm{~m}$. OJP adalah Dataran Batuan Beku (Large Igneous Province, LIP) yang terluas di bumi, seperti diilustrasikan dalam Gambar 1.

Dalam sebuah eksperimen seismik, Gomer dan Okal [1], disebut paper 1, menggunakan analisa seismogram broad-band dari sebuah gempa bumi dalam C050296F (511,2 km) pada dua stasiun observasi, masing-masing di PATS dan CTAO untuk menginterpretasikan sifat mantel di bawah OJP melalui analisa selisih waktu tiba gelombang $\mathrm{ScS}_{2}-\mathrm{ScS}$ (travel time differential), lihat gambar 2. Selisih waktu diukur melalui proses korelasi silang antara gelombang $\mathrm{ScS}_{2}$ dengan gelombang ScS pada data seismogram broad-band. Pada daerah ini mereka mendapatkan selisih waktu tempuh antara gelombang $\mathrm{ScS}_{2}$ dan $\mathrm{ScS}$ terukur dengan referensi sebesar 3 detik, ini mengindikasikan bahwa struktur bumi di bawah OJP memiliki nilai kecepatan yang negatif dibandingkan dengan struktur kecepatan dalam model bumi isotrop PREM [2] .

Dalam suatu eksperimen monitoring seismik gempa-gempa bumi sebelumnya yang menggunakan empat stasiun tersebar di sekitar Pulau Caroline dan Nauru, Richardson et al.[3], disebut sebagai paper 2, menggunakan metoda Partial Waveform Inversion (PWI) pada gelombang Rayleigh. Metoda ini digunakan untuk memperoleh suatu gambaran tomografi atas kulit bumi di bawah OJP. Mereka menemukan bahwa rata-rata ketebalan kulit bumi di daerah ini adalah $33 \mathrm{~km}$ dan ketebalan maksimum $38 \mathrm{~km}$ arah ke selatan dari dasar laut tinggi OJP. Nilai-Nilai kerak bumi dengan ketebalan serupa telah dilaporkan untuk struktur kulit bumi lautan lain, yang dipercaya mempunyai bentuk dekat dengan pegunungan api tengah lautan, mencakup plato Tuamotu ( 25-32 km) [4], ridge Iceland-Færæ (25-30 km) [5], dan ridge Nazca (18 km) [6]. 


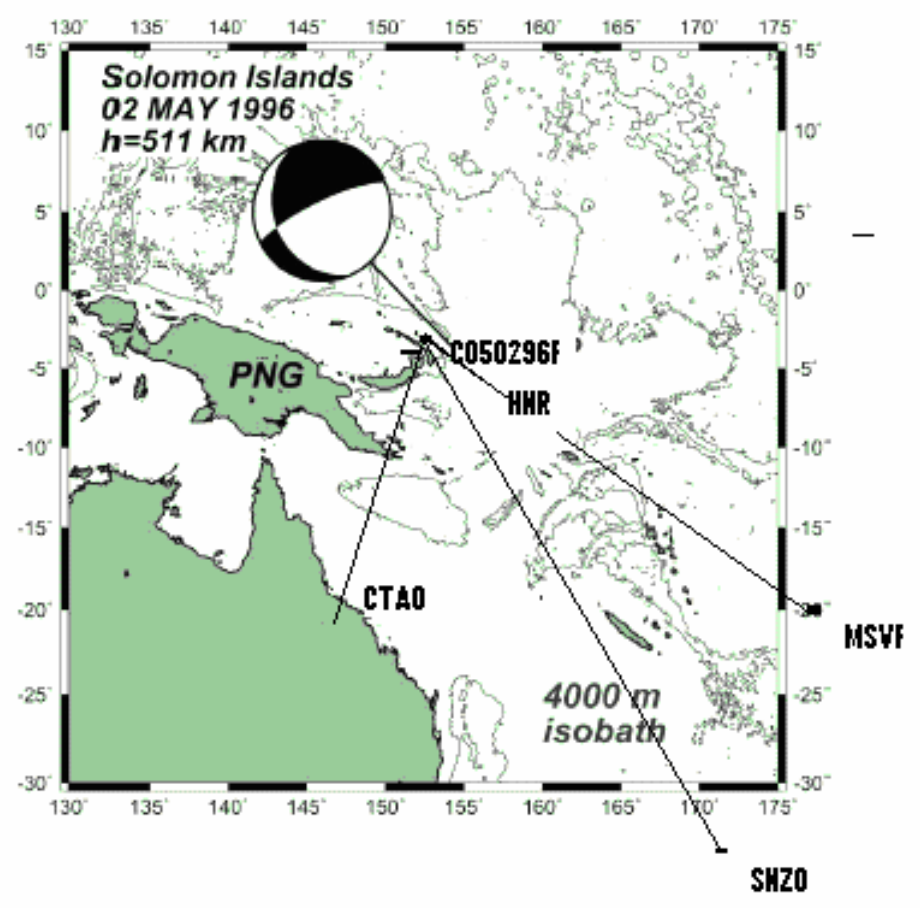

Gambar 1 Peta dari area yang dikaji, termasuk Plato Ontong-Jawa, timur dibatasi oleh Papua New Guinea (PNG) dengan isobath $4000 \mathrm{~m}$.

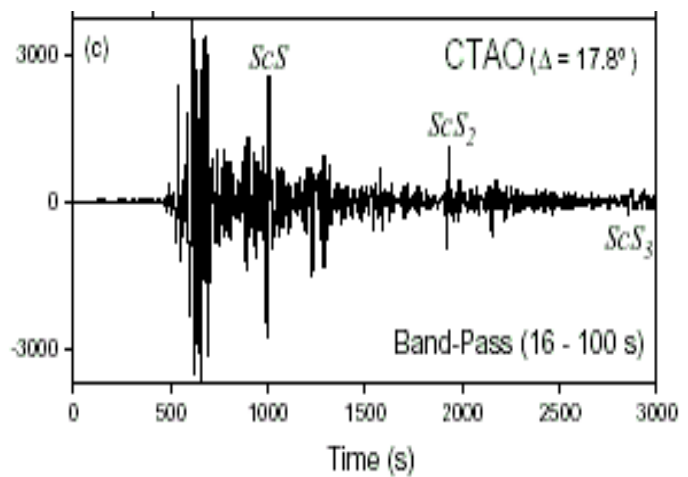

Gambar 2 Seismogram broad band di filter bandpass (16-100 s) yang digunakan dalam kajian [1], di stasiun CTAO.

Kedua artikel [1, 3] terdahulu ini menghasilkan model bumi dengan struktur kecepatan negatif hingga kedalaman $300 \mathrm{~km}$ di bawah OJP, dengan dimensi lateral $600 \mathrm{~km}$. Kedua paper ini menginterpretasikan defisiensi kecepatan 
gelombang S hingga 5 \% dibandingkan dengan PREM, yaitu mencapai nilai di bawah $4 \mathrm{~km} /$ detik. Struktur kecepatan rendah pada kedalaman seperti itu telah sebelumnya dilaporkan hanya dalam area-area yang mengandung pusat-pusat pemekaran kulit bumi aktif, seperti di Iceland [7] , dan pada daerah-daerah yang terkait dengan anomali panas.

Kedua paper terdahulu ini mengambil sedikit informasi dalam seismogram, yaitu selisih waktu tiba dan bentuk gelombang, tetapi hanya pada 1 komponen z dan pada gelombang permukaan Rayleigh saja. Riset ini merupakan tinjauan kritis atas artikel dari Gomer dan Okal [1] dimana riset ini memiliki kesamaan atas gempa yang dianalisa, yaitu gempa dalam C050296F. Perbedaan cara menganalisa seimogram adalah membanding-kan semua ragam gelombang $\mathrm{S}$ dan repitisinya dalam domain waktu dan ketiga komponen simultan, bukan semata waktu-waktu tiba gelombang dalam saja.

\subsection{Teori Penjalaran Gelombang (GEMINI)}

Dalam pembahasan berikut akan dituliskan secara ringkas sistim persamaan pergerakan partikel tanah akibat perambatan gelombang, yang dihasilkan oleh suatu pemberian usikan dalam struktur bumi. Sistim ini merupakan pokokpokok metoda matematis untuk program GEMINI, dimana seismogram sintetik dihitung dengan penyelesaian sistim persamaan tersebut dalam kawasan frekuensi kompleks.

Secara umum pergerakan tanah adalah sebuah sistim diferensial terhadap waktu, yang mana turunannya menjadi hilang ketika ditransformasikan dalam kawasan frekuensi.

$$
-\rho \omega^{2} \vec{u}=\nabla \cdot \sigma+\vec{f} .
$$

dimana $\vec{u}$ adalah vektor pergerakan tanah, $\sigma$ adalah tensor tegangan (stres) dan $\vec{f}$ merupakan vektor gaya.

Karena bumi digambarkan sebagai bola, sistim koordinat yang digunakan adalah spheris. Pergeseran, divergensi tegangan dan gaya diungkapkan sebagai :

$$
\begin{aligned}
& \vec{u}=U \vec{e}_{r}+\nabla_{1} V-\vec{e}_{r} \times \nabla_{1} W \\
& \sigma=R \vec{e}_{r}+\nabla_{1} S-\vec{e}_{r} \times \nabla_{1} T \\
& \vec{f}=G \vec{e}_{r}+\nabla_{1} H-\vec{e}_{r} \times \nabla_{1} K
\end{aligned}
$$


dimana $U, V$, dan $W$ adalah komponen pergerakan tanah dalam arah vertikal, barat-timur dan utara-selatan. Sumber gempa diandaikan terletak di kutub utara, dan begitu pula pada penguraian atas divergensi tegangan $R, S$ dan $T$ dan vektor gaya $G, H$ dan $K$, dan gradien permukaan adalah

$$
\nabla_{1}=\vec{e}_{\theta} \frac{\partial}{\partial \theta}+\frac{\vec{e}_{\wp}}{\sin \wp} \frac{\partial}{\partial \wp}
$$

Melalui hukum Hooke dideskripsikan hubungan antara pergeseran dan tegangan. Dengan memanfaatkan deret ekspansi fungsi harmonik spheris komponen pergerakan tanah dan tegangan dapat dituliskan sebagai, misal untuk $U$

$$
U(r, \theta, \wp, \omega)=\sum_{l=\mathbf{0}}^{\infty} \sum_{m=-l}^{l} U_{l}^{m}(r, \omega) Y_{l}^{m}(\theta, \wp)
$$

dimana adalah $U_{l}^{m}(r, \omega)$ koefisien penderetan dan $Y_{l}^{m}(\theta, \wp)$ adalah fungsi harmonik sferis. Bentuk persamaan gelombang dapat diturunkan menjadi himpunan persamaan diferensial orde satu dengan dimensi 6 kali satu,

$$
\frac{d}{d r} \vec{y}(r)=A(r) \vec{y}(r)+\vec{z}(r)
$$

tiga komponen pertama matriks $A$ untuk pergerakan tanah dalam komponen vektor satuan bola, dan tiga berikutnya adalah tegangan, yang juga dalam arah vektor satuan bola.

Bentuk persamaan diferensial untuk gerak sferoidal, berupa sistem $4 \times 4$ :

$$
\begin{gathered}
\frac{d \tilde{U}_{l}^{m}}{d r}=\frac{-2}{r} \frac{\tilde{F}}{\tilde{C}} \tilde{U}_{l}^{m}+\frac{1}{\tilde{C}} \tilde{R}_{l}^{m}+\frac{l(l+1) \tilde{F}}{r \tilde{C}} \tilde{V}_{l}{ }^{m}+\frac{2}{r}\left(\frac{\tilde{F}}{\tilde{C}}-1\right) \tilde{R}_{l}^{m} \\
\frac{d \tilde{R}_{l}^{m}}{d r}=\left[-\rho_{0} \omega^{2}+\frac{4}{r^{2}}\left(\tilde{A}-\frac{\tilde{F}^{2}}{\tilde{C}}-\tilde{N}\right)\right] \tilde{U}_{l}^{m} \\
-\frac{2 l(l+1)}{r^{2}}\left(\tilde{A}-\frac{\tilde{F}^{2}}{\tilde{C}}-\tilde{N}\right) \tilde{V}_{l}^{m}+\frac{l(l+1)}{r} \tilde{S}_{l}^{m}-\tilde{G}_{l}^{m} \\
\frac{d \tilde{V}_{l}^{m}}{d r}=\frac{-1}{r} \tilde{U}_{l}^{m}+\frac{1}{r} \tilde{V}_{l}^{m}+\frac{1}{\tilde{L}} \tilde{U}_{l}^{m} \\
\frac{d \tilde{S}_{l}^{m}}{d r}=\frac{-2}{r^{2}}\left(\tilde{A}-\frac{\tilde{F}^{2}}{\tilde{C}^{2}}-\tilde{N}\right) \tilde{U}_{l}^{m}-\frac{\tilde{F}}{r \tilde{C}} \tilde{R}_{l}^{m} \\
\text { dan }+\left[-\rho_{0} \omega^{2}+\frac{l(l+1)}{r^{2}}\left(\tilde{A}-\frac{\tilde{F}^{2}}{\tilde{C}^{m}}\right)-\frac{2 \tilde{N}^{2}}{r}\right] \tilde{V}_{l}^{m}-\frac{3}{r} \tilde{S}_{l}^{m}-\tilde{H}_{l}^{m}
\end{gathered}
$$




$$
\begin{aligned}
& \frac{d \tilde{W}_{l}^{m}}{d r}=\frac{\mathbf{1}}{\widetilde{L}} \tilde{T}_{l}^{m}+\frac{\mathbf{1}}{r} \tilde{W}_{l}^{m} \\
& \frac{d \tilde{T}_{l}^{m}}{d r}=-\rho_{\mathbf{0}} \omega^{2} \tilde{W}_{l}^{m}-\frac{\mathbf{3}}{r} \tilde{T}_{l}^{m}-\frac{\tilde{N}}{r^{2}}[\mathbf{2}-l(l+\mathbf{1})] \tilde{W}_{l}^{m}-\tilde{K}_{l}^{m}
\end{aligned}
$$

Arti dari notasi tilde di atas besaran- besaran fisis adalah kegayutan atas frekuensi kompleks [8].

Di sini kita dapat melihat, bahwa kedua parameter elastik $L$ dan $N$ eksis dalam persamaan gerak $(V$ dan $W$ ). Kedua paarameter ini memberikan pengaruh besar pada gelombang permukaan Love dan Rayleigh.

Pengembangan atas koefisien harmonik sferis juga dikenakan pada suku-suku dalam moment tensor gempa bumi, yang mana gaya dapat diungkapkan sebagai divergensi dari tegangan,

$$
\mathrm{f}=-\nabla \cdot \mathrm{m}
$$

sehingga ekspansi harmonik sferis atas gaya mengandung koefisien dengan fungsi $\delta$ (indeks 1 ) dan turunan pertamanya terhadap r (indeks 2)

$$
z(r)=z_{1} \delta\left(r-r_{s}\right)+z_{2} \frac{d}{d r} \delta\left(r-r_{s}\right)
$$

Ekspansi fungsi solusi atas harmonik sferis ini kemudian disisipkan kembali pada persamaan gelombang dan hasilnya berupa sistim differensial orde satu. Dalam sistim persamaan orde satu ini, parameter elastik bahan padat masuk pada komponen matriks kernel. Guna melibatkan sifat anelastisitas bumi, frekuensi riil $\omega$ diubah menjadi frekuensi kompleks dengan menambahkan sebuah bilangan imaginer positif kecil, dinotasikan dengan $\sigma$, menjadi $\omega+1 \sigma$.

Sistim persamaan ini kemudian diintegrasikan dari titik tengah inti bumi, atau dari sebuah jejari, dimana amplitudo sebuah fase gelombang di jejari tersebut telah meluruh secara eksponensial dengan cepat [9] hingga ke kedalaman sumber gempa, hasil integral dinotasikan dengan $\mathbf{g}_{1}$ dan $\mathbf{g}_{2}$. Selain itu sistim persamaan juga diintegrasikan dari permukaan bumi hingga ke kedalaman sumber gempa, dinotasikan dengan $\mathbf{w}_{1}$ dan $\mathbf{w}_{2}$. Nilai awal solusi diberikan dengan memperhatikan kondisi syarat batas, yaitu di permukaan tegangan sama dengan nol dan di perbatasan padat cair, tegangan geser menghilang. Hasil solusi integrasi dari bawah dan atas, disebut sebagai fungsi-fungsi Green. Fungsi-fungsi Green ke atas dan ke bawah kemudian dikurangkan dan hasilnya disamakan dengan koefisien-koefisien ekspansi sumber 


$$
\begin{aligned}
s & =y\left(r_{s}+\mathbf{0}\right)-y\left(r_{s}-\mathbf{0}\right) \\
& =z_{1}+A\left(r_{s}\right) \cdot z_{2}
\end{aligned}
$$

Untuk masing-masing pergerakan sferoidal dan toroidal penyelesaian amplitudo fungsi diselesaikan dengan aturan Cramer.

$$
c_{1} g_{2}\left(r_{s}\right)+c_{2} g_{2}\left(r_{s}\right)-d_{\mathbf{1}} w_{\mathbf{1}}\left(r_{s}\right)-d_{2} w_{\mathbf{2}}\left(r_{s}\right)=s\left(r_{s}\right)
$$

Solusi persamaan linear dengan aturan Cramer ini menuntut eksistensi determinan, yang dibentuk sebagai produk atas nilai-nilai fungsi-fungsi Green pada kedalaman sumber, yang bersifat terhingga (finite). Namun pada frekuensi eigen bumi, determinan mempunyai nilai nol. Karena juga kelemahan sistim numerik, nilai-nilai fungsi Green atas dan bawah mempunyai orde-orde yang besar, namun selisih-selisih dari hasil perkalian fungsi Green ternyata orde-nya lebih kecil dari 'round-off' numerik.

Untuk mengatasi kesulitan-kesulitan tersebut, sistim persamaan diferensial diubah langsung ke dalam bentuk perhitungan atas diferensial minor (dari minor-minor dalam matrik di atas). Sistim persamaan diferensial minor ini kemudian diselesaikan dengan metoda integrasi sistim persamaan diferensial. Deskripsi lengkap atas teori penjalaran gelombang dalam medium bumi dapat dilihat pada artikel dari Dalkolmo [9]. Dengan demikian amplitudo fungsi Green, masih dalam kawasan frekuensi kompleks dan ekspansi harmonik sferis, dapat diselesaikan untuk sebuah model bumi dengan parameter elastik yang lengkap dan untuk sebuah kedalaman dan kekuatan sumber gempa bumi. Jarak episentral dan azimuth stasiun tersebut terhadap titik sumber gempa diberikan, dan dari parameter koordinat bola ini dilakukan penjumlahan lengkap atas ekspansi fungsi harmonik sferis dan setelah itu dilakukan transformasi Fourier balik, sehingga diperoleh seismogram sintetik.

\section{$2 \quad$ Metodologi}

Metoda yang digunakan dalam artikel ini berbeda dengan metoda yang telah digunakan oleh peneliti-peneliti sebelumnya. Mereka menggunakan waktu tempuh residual dalam studi awal untuk penyelidikan heterogenitas dalam mantel atas $[10,11]$. Selisih waktu tempuh diukur dengan melakukan korelasi silang antara dua fase gelombang, $\mathrm{ScS}$ dan $\mathrm{ScS}_{2}$, dimana sebagai patokan diambil selisih waktu tiba gelombang-gelombang sintetik serupa yang dihitung dari model bumi isotrop PREM. Untuk menghitung seismogram sintetik digunakan metoda reflektivitas, dimana bumi bulat berlapis didekati dengan bumi berlapis mendatar melalui earth-flattening transformation (EFT). Dalam 
metoda selisih waktu tiba ini sifat anisotropi dalam lapisan-lapisan bumi tidak diaplikasikan sama sekali.

Seismogram sintetik dihitung dengan metoda Gemini [9, 12], dimana tidak diperlukan pendekatan EFT. Response file dari sistim peralatan seismometer di stasiun penerima, yaitu deskripsi tentang perubahan fase dan amplifikasi dari sistim peralatan ketika mengubah input dalam kecepatan/ percepatan pergerakan tanah menjadi output tegangan $[\mathrm{mV}]$, dikenakan pada seismogram terukur, sehingga seismogram sintetik dan seismogram terukur dibandingkan dalam satuan yang sama. Pada kedua seismogram, terukur dan sintetik dikenakan filter lolos rendah Butterworth untuk menyederhanakan pengamatan atas diskrepansi bentuk gelombang.

Dalam riset ini, seismogram terukur dibandingkan dengan seismogram sintetik yang dihitung dari model bumi PREMAN [2] (versi vertikal anisotropi dari PREM), dalam domain waktu dan ketiga komponen Kartesian simultan. Selisih waktu tempuh dan bentuk gelombang didapatkan dengan mengukur perbandingan seismogram terukur dan sintetik secara langsung, yaitu letak maksimum atau minimum dari fase gelombang diukur waktu tibanya, terlambat atau tiba lebih awal dan juga bentuk gelombangnya [13].

Gempa bumi yang dianalisa adalah gempa bumi C050296F, Kepulauan Solomon, yang terjadi pada 02 Mei 1996, pada lokasi 4,55 LS, 154,83 BT dan kedalaman 511,2 km, dengan mekanisme fokal $\phi=25^{\circ}, \delta=73^{0}, \lambda=-111^{0}$ [14]. Hiposenter ini terletak dalam rangkaian Gunung Api Pasifik, terletak pada bidang tumbukan subduksi antara kerak bumi Lautan Pasifik dengan OJP. Stasiun-stasiun observasi yang digunakan untuk menganalisa seismogram gempa ini terletak pada berbagai arah terhadap letak episenter gempa, seperti dapat dilihat dalam Tabel 1. Riset ini menganalisa bentuk gelombang dalam seismogram di empat stasiun observasi yaitu HNR, CTAO, MSVF dan SNZO, sedangkan paper terdahulu [1] hanya menganalisa waktu-waktu tiba (lihat gambar 2) dalam seismogram broad-band dari dua stasiun observasi saja, yaitu PATS dan CTAO. Data-data rekaman seismogram kami peroleh dari IRIS (Incorporated Research Institutions for Seismology) dan hanya pada keempat stasiun-stasiun observasi tersebut data Long Period dapat kami peroleh. Kami telah mencoba untuk memesan data Long Period dari stasiun PATS, namun IRIS memberikan respons bahwa tidak ada data Long Period dari stasiun tersebut.

Riset mereka [1, 3] hanya menganalisa selisih waktu-waktu tiba gelombang ScS dan $\mathrm{ScS}_{2}$. Mereka tidak memperhatikan, bahwa gempa yang dalam dan kuat memberikan kesempatan pada seismolog untuk mempelajari struktur bumi dengan memperhatikan gelombang dalam dan gelombang dalam yang upward. 
Garis-garis lurus antara kedudukan sumber gempa dan stasiun-stasiun observasi, seperti yang ditunjukkan dalam Gambar 1, menyajikan proyeksi vertikal dari penjalaran gelombang dari hiposenter ke stasiun observasi yang digunakan dalam riset ini. Jalan gelombang dari hiposenter gempa ke stasiun HNR dan MSVF melintasi OJP sepenuhnya, dimana kedua stasiun ini masingmasing terletak di Kep. Solomon dan Kep. Fiji. Saya tidak dapat menggambarkan kedudukan dua stasiun observasi lainnya dalam kotak gambar 1, yakni MSVF dan SNZO, karena gambar 1 adalah hasil kopi dari referensi 1, sedangkan kedudukan kedua stasiun tersebut berada di luar rentang koordinatnya. Untuk memproduksi sendiri gambar 1, kami tidak memiliki data GMT resolusi tinggi untuk kontur muka bumi dan dasar laut.

Tabel 1 Stasiun-stasiun observasi yang digunakan dalam riset ini.

\begin{tabular}{cccc}
\hline No & Lintang & Bujur & Stasiun \\
\hline 1 & $-9,43$ & 159,95 & HNR, Honiara, Solomon Islands \\
2 & $-18,08$ & 178,25 & MSVF, Monasafu, Viti Levu, Fiji \\
3 & $-20,09$ & 146,25 & CTAO, Charters Towers, Quensland \\
4 & $-41,76$ & 174,7 & SNZO, New Zealand \\
\hline
\end{tabular}

Gambar-gambar berikut menyajikan perbandingan dan pencocokan seismogram pada gelombang Love, Rayleigh, SS, $\mathrm{S}$ dan gelombang dalam $\mathrm{ScS}$ dan $\mathrm{ScS}_{2}$ dan juga $\mathrm{sScS}$ dan $\mathrm{sScS}_{2}$, untuk mendapatkan struktur kecepatan $\beta$ pada lapisanlapisan bumi dangkal hingga kedalaman CMB (Core Mantle Boundary). Tiap gambar memuat 3 komponen, masing-masing ditandai dengan $\mathrm{z}$ untuk vertikal, $\mathrm{r}$ untuk radial dan t untuk transversal. Dalam tiap komponen ada 3 kurva, dimana kurva mulus adalah data terukur, kurva titik-titik adalah seismogram sintetik yang dibentuk dari model bumi PREMAN, dan kurva garis-titik adalah pencocokan seismogram yang diperoleh dengan menggunakan model bumi dikoreksi, yang terpampang pada kotak kecil di sisi kanan sebagai kurva garistitik. Secara umum, untuk mendapatkan pencocokan, gradien kecepatan $\beta_{\mathrm{h}}$ di mantel atas diubah menjadi positif terhadap kedalaman, daripada negatif seperti pada PREMAN. Sedangkan gradien untuk $\beta_{\mathrm{v}}$ dibiarkan seperti pada PREMAN, perubahan hanya dilakukan pada koefisien orde nol pada polinomial yang menggambarkan fungsi kecepatan di tiap-tiap lapisan bumi.

\section{$3 \quad$ Hasil Riset dan Diskusi}

\subsection{Hasil Riset}

Gambar 3a menunjukkan perbandingan seismogram di stasiun HNR, yang berjarak $7,0^{0}$ dari hiposenter. Dengan jarak sekecil ini, seismogram tergolong pada strong motion, kita dapat melihat bahwa program GEMINI masih dapat 

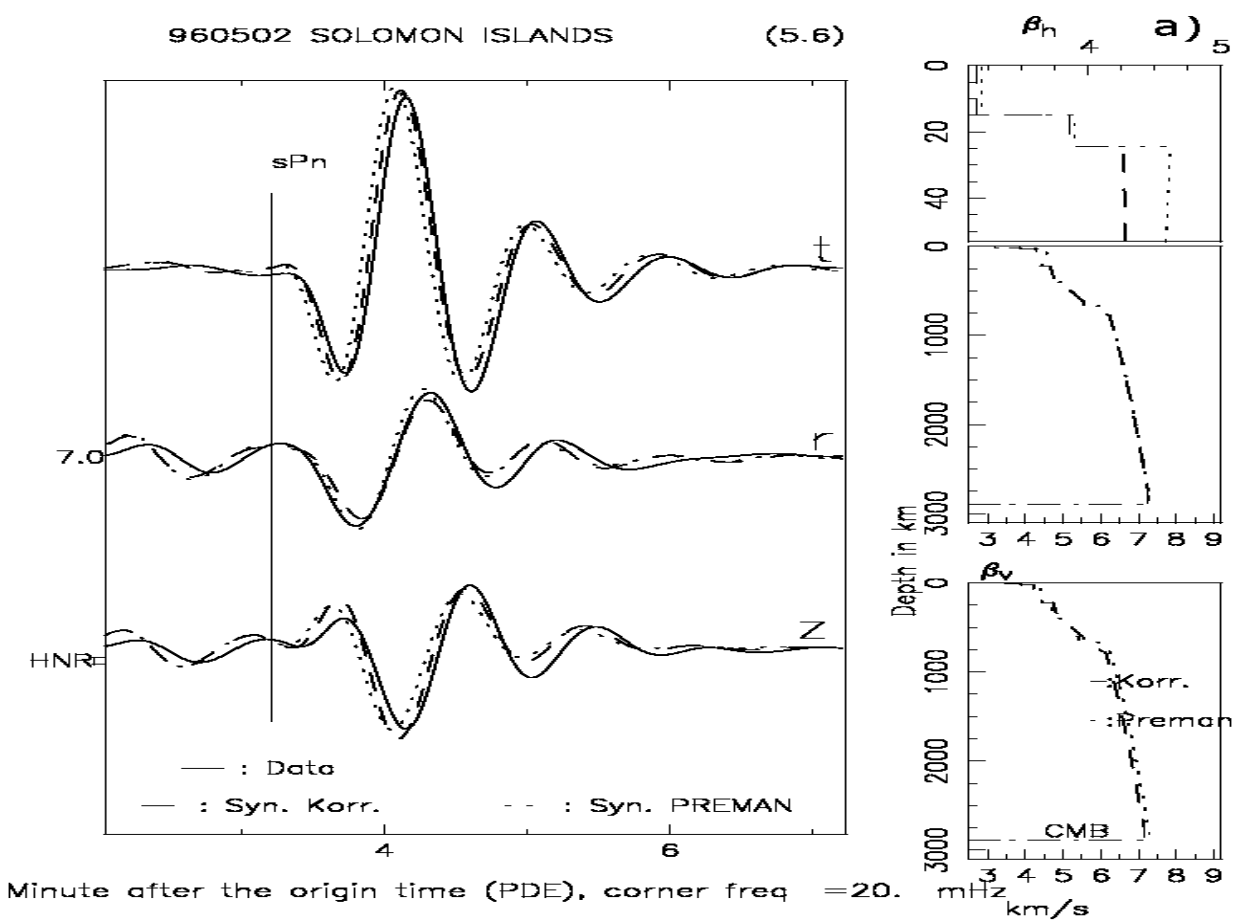

Minute after the origin time (PDE). corner freq $=20$.

(5.6) b)

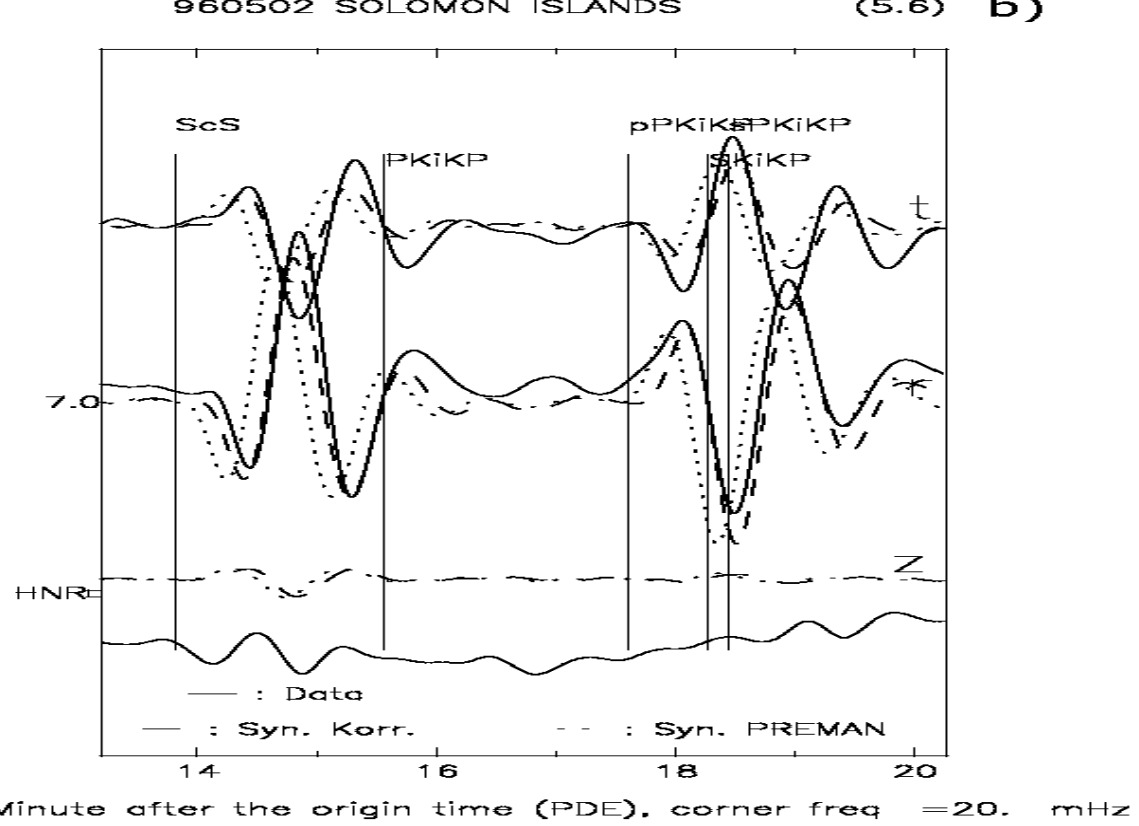

Gambar 3 Perbandingan seismogram terukur dan sintetik di stasiun observasi HNR pada gelombang a. S, Love dan Rayleigh; b. ScS dan sScS. 

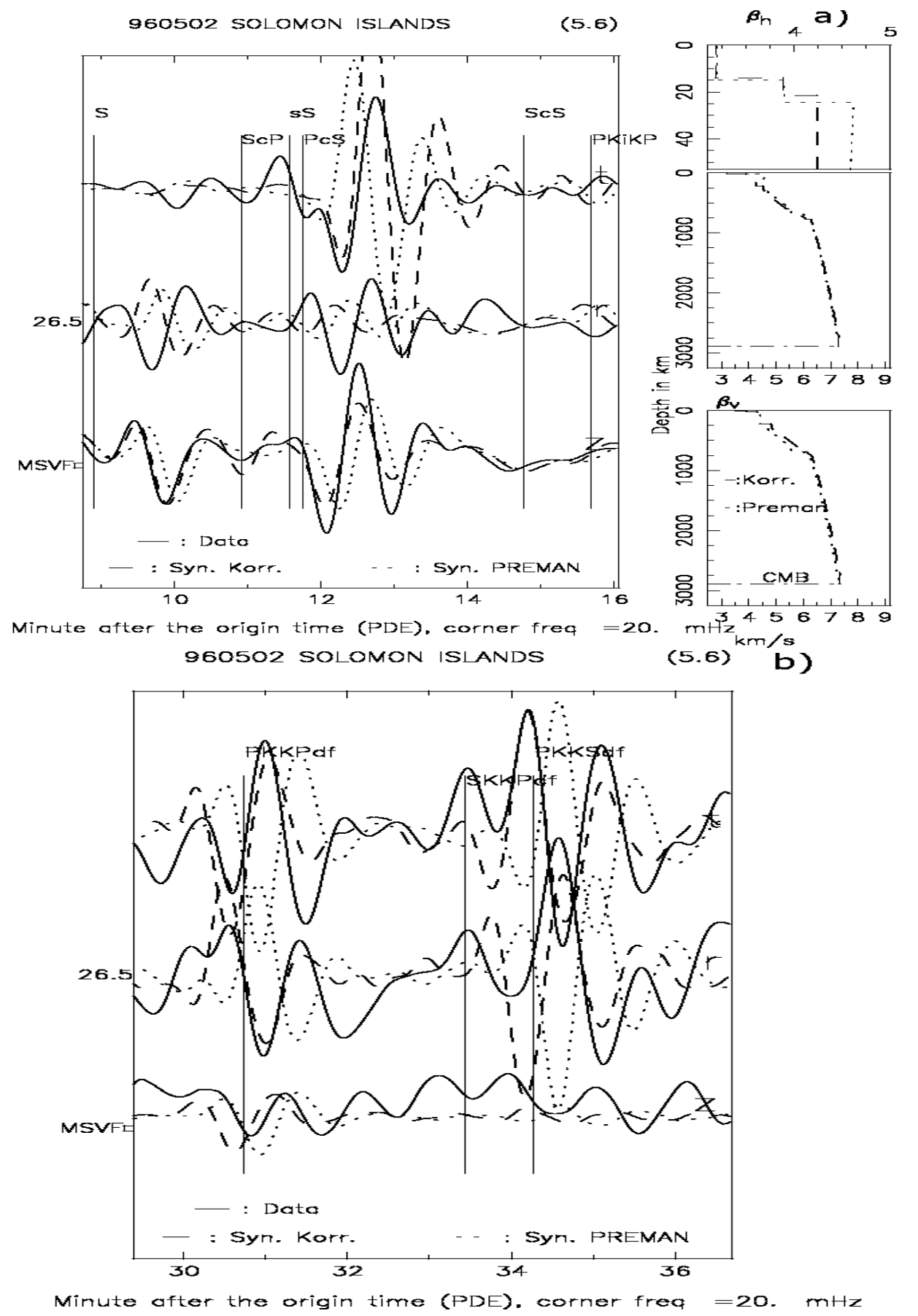

Gambar 4 Perbandingan seismogram terukur dan sintetik di stasiun observasi MSVF pada gelombang a. S, Love dan Rayleigh; b. $\mathrm{ScS}_{2}$ dan $\mathrm{sScS}_{2}$. 
menghasilkan seismogram strong motion dan kita melihat bahwa gelombang $\mathrm{S}$ tenggelam dalam gelombang permukaan Love yang memiliki amplitudo sangat besar, sehingga pengukuran waktu tiba gelombang $S$ untuk stasiun pada jarak episentral kecil sangat sulit. Gambar 3a menunjukkan bahwa pencocokan yang bagus dapat dicapai pada gelombang Love dan Rayleigh di komponen r, sementara waveform Rayleigh sintetik di komponen z masih datang lebih awal. Untuk mendapatkan pencocokan pada kedua komponen di $\mathrm{r}$ dan t, struktur kecepatan $\beta_{\mathrm{v}}$ vertikal dan $\beta_{\mathrm{h}}$ horisontal di mantel atas diubah, pada koefisien orde nol pada polinomial kecepatan di lapisan-lapisan tersebut (lihat struktur kecepatan di model bumi PREM) dan gradien kecepatan $\beta_{\mathrm{h}}$ di mantel atas diubah menjadi positif terhadap kedalaman. Bandingkan dengan penggunaan gradien negatif di mantel atas pada model bumi PREMAN. Gambar 3b menunjukan pencocokan yang sangat bagus untuk gelombang dalam ScS dan yang upgoing dan direfleksikan oleh permukaan bumi sScS. Fase-fase gelombang ini dalam penjalarannya melintasi semua lapisan-lapisan mantel bumi, dari permukaan bumi hingga batas Inti-Mantel (CMB). Pencocokan ini dicapai dengan mengenakan koreksi kecepatan negatif pada semua lapisanlapisan bumi, sementara analisa dalam paper 2 dengan PWI pada gelombang Rayleigh hanya dapat menginterpretasikan struktur kecepatan $\beta_{\mathrm{v}}$ dengan anomali negatif hingga kedalaman $300 \mathrm{~km}$. Pencocokan dicapai pada kedua fase gelombang ScS dan fase gelombang bayangannya sScS, sementara paper 1 hanya dapat mengukur beda selisih waktu tiba antara gelombang $\mathrm{ScS}$ dan $\mathrm{ScS}_{2}$ saja, dimana pengukuran dilakukan hanya pada komponen z semata. Sedangkan untuk referensi digunakan selisih waktu tiba gelombang yang dihitung dari model bumi isotrop PREM. Sedangkan penelitian ini mendapatkan pencocokan yang bagus pada bentuk gelombang ScS dan sScS di kedua komponen $\mathrm{r}$ dan $\mathrm{t}$. Struktur kecepatan gelombang $\mathrm{S}$ pada gambar-gambar berikutnya hanya ditunjukkan hingga kedalaman $730 \mathrm{~km}$, semata untuk memperjelas koreksi kecepatan pada lapisan-lapisan mantel teratas.

Berikutnya kita lihat, bagaimana perbandingan seismogram gempa ini jika analisa dilakukan pada stasiun MSVF yang terletak di Kepulauan Fiji, dengan jarak episentral 26,5 . Gambar 4a menunjukkan bahwa pencocokan hanya dapat dicapai pada komponen $\mathrm{z}$ dan $\mathrm{t}$, sedangkan data terukur di komponen $\mathrm{r}$ tidak sefase sama sekali dengan data di komponen z. Anomali yang teramati pada gelombang permukaan adalah bahwa gelombang Love sintetik dari PREMAN tiba lebih awal daripada gelombang sepadan terukur, sedangkan gelombang Rayleigh sintetik PREMAN tiba sedikit lebih lambat. Sementara gelombang SV sintetik dari PREMAN di komponen z tiba lebih akhir daripada SV terukur. Ini mengindikasikan bahwa anomali kecepatan $\beta_{\mathrm{h}}$ di mantel atas memiliki anomali negatif, sedangkan koreksi untuk $\beta_{\mathrm{v}}$ bernilai positif untuk mantel atas, di daerah bawah sepanjang OJP ke arah tenggara. Koreksi positif ini berlanjut pada 

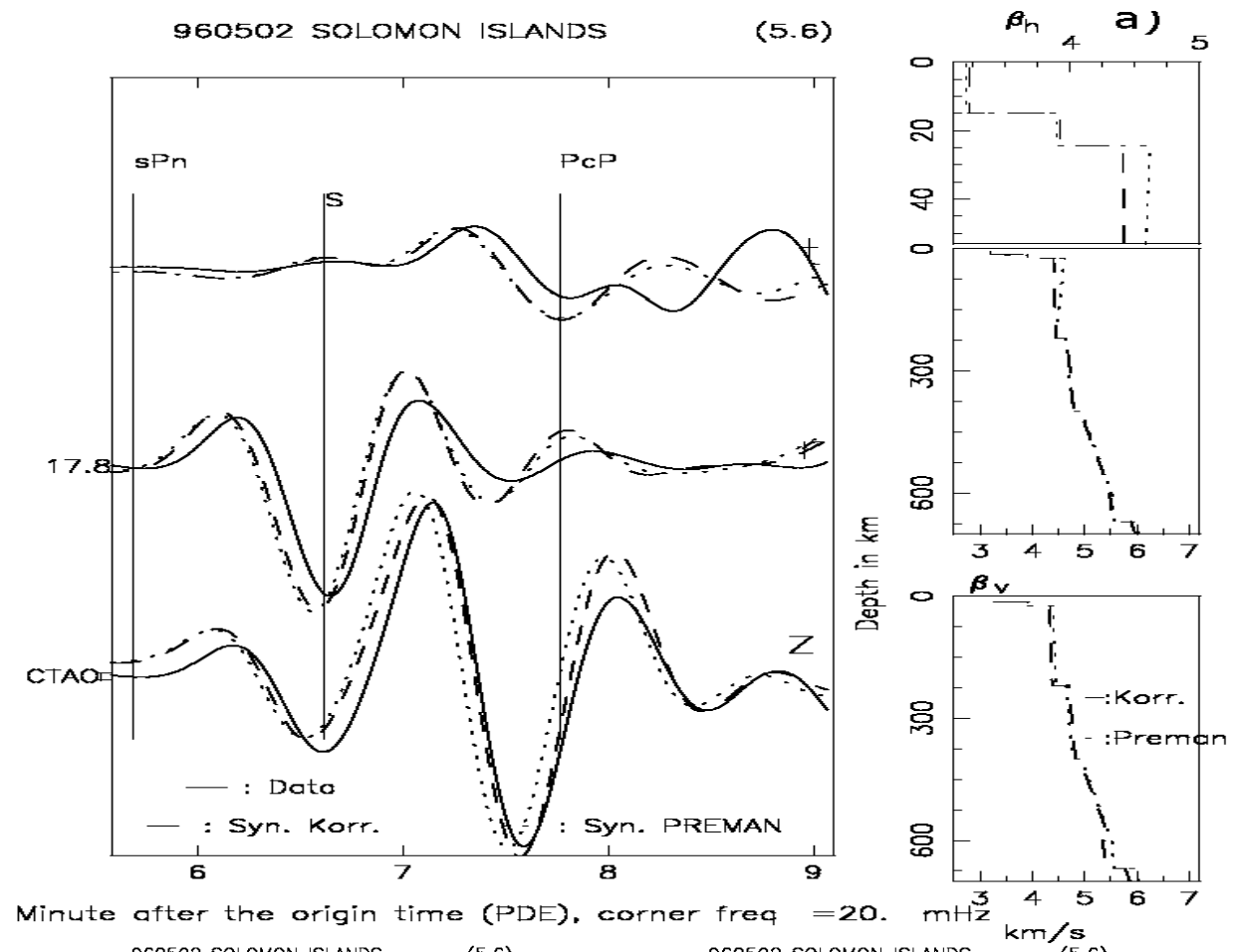

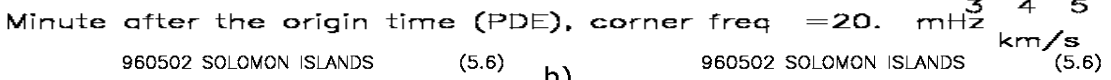
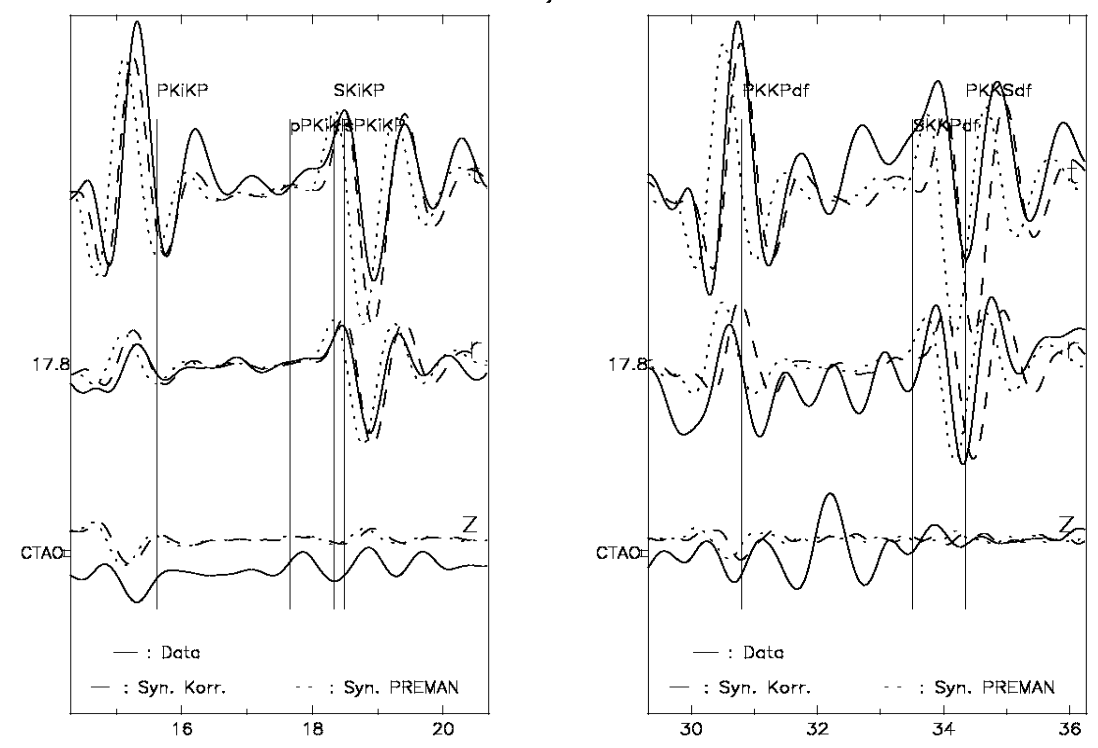

Minute after the origin time (PDE), corner freq $=20$. $m H z$ Minute after the origin time (PDE), corner freq $=20$. $m H z$

Gambar 5 Perbandingan seismogram terukur dan sintetik di stasiun observasi CTAO pada gelombang : a. S; b. ScS dan sScS; c. $\mathrm{ScS}_{2}$ dan $\mathrm{sScS}_{2}$. 
lapisan-lapisan bumi di bawah lithosfer hingga CMB, karena gelombang S sintetik menunjukkan keterlambatan. Anomali kecepatan positif pada lapisanlapisan bumi di bawah lithosfer diperlukan, untuk mendapatkan pencocokan pada gelombang $\mathrm{ScS}_{2}$ dan $\mathrm{sScS}_{2}$, seperti diilustrasikan dalam Gambar 4b. Hasil pencocokan ini, dimana menunjukkan anomali positif untuk lapisan-lapisan bumi, berbeda dengan hasil interpretasi model bumi dalam paper 1 dan paper 2 .

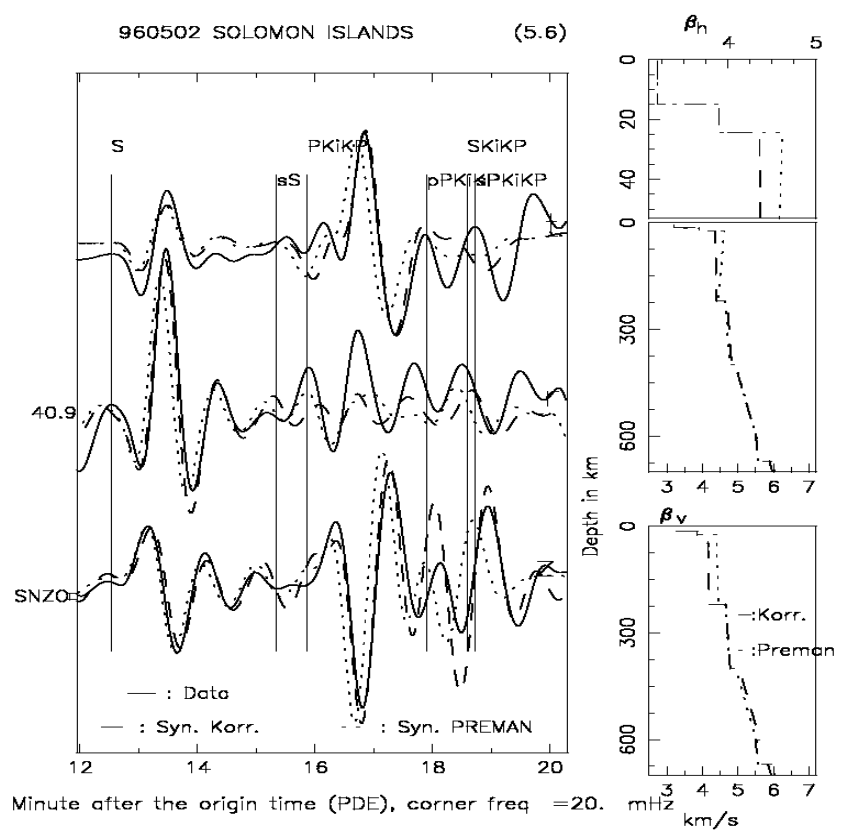

Gambar 6 Perbandingan seismogram terukur dan sintetik di stasiun observasi SNZO, pada gelombang S, Love dan Rayleigh.

Gambar 5 menyajikan perbandingan seismogram terukur dengan sintetiksintetiknya dari model bumi PREMAN dan dikoreksi di stasiun observasi CTAO. Terlihat bahwa model bumi PREMAN memberikan sintetik yang datang sedikit lebih awal daripada fase gelombang terukur sepadan, terjadi pada gelombang $\mathrm{S}$ dan gelombang dalam $\mathrm{ScS}$ dan $\mathrm{ScS}_{2}$ dan bayangan-bayangannya (gelombang dalam yang upgoing dan dipantulkan kembali oleh permukaan bumi). Ini menunjukkan bahwa anomali khususnya di lapisan mantel atas ke arah Barat Daya dari OJP sungguh bernilai negatif, sebagaimana telah dihasilkan oleh Richardson et al. [3]. Tetapi koreksi negatif juga harus dikenakan pada lapisan-lapisan mantel hingga CMB, tidak hanya pada $300 \mathrm{~km}$ lapisan bumi teratas.

Gambar 6 menunjukkan perbandingan seismogram di stasiun SNZO, Selandia Baru. Terlihat bahwa dalam jarak episentral yang cukup besar, gelombang S, SS 
dan Love terpisah dengan baik, namun gelombang sintetik dari PREMAN tiba sedikit lebih awal daripada fase gelombang terukur. Ini menunjukkan bahwa model bumi arah Selatan Timur OJP memiliki anomali negatif dibandingkan dengan struktur kecepatan seperti dalam model bumi PREMAN.

\subsection{Diskusi}

Tabel 2 menyajikan koefisien-koefisien dari polinomial yang mendeskripsikan struktur kecepatan S di tiap-tiap lapisan mantel [2].

Tabel 2 Koefisien-koefisien orde nol fungsi polinomial kecepatan $\mathrm{S}$ di tiaptiap lapisan mantel, fungsi polinomial dapat dilihat lebih rinci pada model bumi PREMAN 2.

\begin{tabular}{|c|c|c|c|c|c|c|}
\hline \multirow{2}{*}{ R bawah } & \multicolumn{2}{|c|}{ PREMAN } & \multicolumn{2}{|c|}{ HNR } & \multicolumn{2}{|c|}{ MSVF } \\
\hline & $\mathbf{B}_{\mathbf{v}}$ & $\boldsymbol{B}_{\mathrm{h}}$ & $\boldsymbol{B}_{\mathbf{v}}$ & $\boldsymbol{B}_{\mathrm{h}}$ & $\mathbf{B}_{\mathbf{v}}$ & $\mathbf{B}_{h}$ \\
\hline $\begin{array}{l}\text { CMB } \\
3480 \mathrm{~km}\end{array}$ & 6,9254 & 6,9254 & 6,8544 & 6,9104 & 7,0054 & 6,9654 \\
\hline 3630 km & 11,1671 & 11,1671 & 11,0971 & 11,1521 & 11,2471 & 11,2021 \\
\hline $5600 \mathrm{~km}$ & 22,3459 & 22,3459 & 22,1659 & 22,2799 & 22,4459 & 22,2099 \\
\hline $5701 \mathrm{~km}$ & 9,9839 & 9,9839 & 9,8839 & 9,9739 & 10.1139 & 9,9039 \\
\hline $5771 \mathrm{~km}$ & 22,3512 & 22,3512 & 22,3712 & 22,3212 & 22,6012 & 22,2112 \\
\hline 5971 km & 8,9496 & 8,9496 & 9.0696 & 8,9596 & 9,1096 & 8,8096 \\
\hline $6151 \mathrm{~km}$ & 5,8582 & $-1,0839$ & 5,7222 & 5,7402 & 5,7522 & 5,6562 \\
\hline $6291 \mathrm{~km}$ & 5,8582 & $-1,0839$ & 5,7222 & 5,7402 & 5,7522 & 5,6562 \\
\hline Moho depth & \multicolumn{2}{|c|}{$25 \mathrm{~km}$} & \multicolumn{2}{|c|}{$25 \mathrm{~km}$} & \multicolumn{2}{|c|}{$22 \mathrm{~km}$} \\
\hline Lower crust & 3,9000 & 3,9000 & 3,9000 & 3,8600 & 3,9000 & 3,8800 \\
\hline Upper crust & 3,2000 & 3,2000 & 3,2000 & 3,1600 & 3,2000 & 3,1800 \\
\hline \multirow{2}{*}{ R bawah } & \multicolumn{2}{|c|}{ PREMAN } & \multicolumn{2}{|c|}{ CTAO } & \multicolumn{2}{|c|}{ SNZO } \\
\hline & $\boldsymbol{B}_{\mathbf{v}}$ & $\boldsymbol{B}_{\mathrm{h}}$ & $\boldsymbol{B}_{\mathrm{v}}$ & $\beta_{h}$ & $\boldsymbol{\beta}_{\mathrm{v}}$ & $\beta_{h}$ \\
\hline $\begin{array}{l}\text { CMB } \\
3480 \mathrm{~km}\end{array}$ & 6,9254 & 6,9254 & 6,8654 & 6,9104 & 6,9254 & 6,9254 \\
\hline 3630 km & 11,1671 & 11,1671 & 11,1071 & 11,1521 & 11,1671 & 11,1671 \\
\hline $5600 \mathrm{~km}$ & 22,3459 & 22,3459 & 22,1759 & 22,2799 & 22,2459 & 22,2799 \\
\hline $5701 \mathrm{~km}$ & 9,9839 & 9,9839 & 9,8139 & 9,9439 & 9,9639 & 9,9739 \\
\hline $5771 \mathrm{~km}$ & 22,3512 & 22,3512 & 22,3212 & 22,3312 & 22,4512 & 22,3412 \\
\hline $5971 \mathrm{~km}$ & 8,9496 & 8,9496 & 8,9996 & 8,9696 & 8,9596 & 8,9996 \\
\hline $6151 \mathrm{~km}$ & 5,8582 & $-1,0839$ & 5,7922 & 5,8306 & 5,6122 & 5,7802 \\
\hline $6291 \mathrm{~km}$ & 5,8582 & $-1,0839$ & 5,7922 & 5,8306 & 5,6122 & 5,7802 \\
\hline Moho depth & \multicolumn{2}{|c|}{$25 \mathrm{~km}$} & \multicolumn{2}{|c|}{$25 \mathrm{~km}$} & \multicolumn{2}{|c|}{$25 \mathrm{~km}$} \\
\hline Lower crust & 3,9000 & 3,9000 & 3,9200 & 3,9200 & 3,8500 & 3,9000 \\
\hline Upper crust & 3,2000 & 3,2000 & 3,2200 & 3,2200 & 3,1500 & 3,2000 \\
\hline
\end{tabular}


Gradien $\beta_{\mathrm{h}}$ di mantel atas untuk PREMAN adalah 5,7176, menunjukkan bahwa arah $\mathrm{R}$ membesar kecepatan $\beta_{\mathrm{h}}$ bertambah (kecepatan berkurang terhadap kedalaman). Sedangkan pada model-model bumi dikoreksi digunakan gradien 1,4278, dimana ke arah $\mathrm{R}$ membesar kecepatan $\beta_{\mathrm{h}}$ berkurang (kecepatan bertambah terhadap kedalaman).

Setelah didapatkan hasil riset, selanjutnya didiskusikan hasil penelitian dengan 2 paper sebelumnya (paper 1 dan paper 2), dimana mereka telah melakukan riset seismologi di daerah yang sama, oleh karena itu diskusi ditekankan pada 3 stasiun semata, yaitu HNR, MSVF dan CTAO. Paper 2 menuliskan bahwa ketebalan kulit bumi di bawah OJP $33 \mathrm{~km}$, dan ke arah selatan $38 \mathrm{~km}$. Setelah perbandingan seismogram di stasiun HNR dan MSVF, ketebalan kulit bumi tetap pada $25 \mathrm{~km}$, sebagaimana pada PREMAN, dengan memperhatikan bentuk gelombang permukaan Love. Mereka menyebutkan bahwa anomali kecepatan negatif di bawah $5 \%$ pada struktur mantel atas, sedangkan riset ini anomali tersebut hanya negatif $2 \%$, didapatkan pada stasiun HNR dan CTAO. Ini berarti hanya hiposenter ke arah timur saja anomali negatif dijumpai. Namun anomali tidak hanya terjadi di $300 \mathrm{~km}$ lapisan bumi teratas, melainkan berlanjut ke lapisan-lapisan bumi di bawahnya. Sedangkan ke arah tenggara, pengamatan seismogram di stasiun MSVF, struktur bumi menunjukkan anomali positif pada lapisan-lapisan bumi dari lithosfer hingga CMB.

Paper 1 menuliskan, bahwa selisih waktu antara $\mathrm{ScS}_{2}$ dengan $\mathrm{ScS}$ di stasiun CTAO sebesar 6 detik, yang berarti untuk satu kali jalan ScS sebesar 3 detik. Mereka menginterpretasikan selisih waktu ini disebabkan oleh inhomogenitas di mantel atas. Riset ini menghasilkan diskrepansi waktu untuk gelombang ScS sebesar 4 detik, sedangkan dua kali jalan tempuh untuk $\mathrm{ScS}_{2}$ sebesar 7 detik. Riset ini tidak memanfaatkan sama sekali gelombang-gelombang dalam upgoing yang terpantul oleh permukan bumi $\mathrm{sScS}$ atau $\mathrm{sScS}_{2}$. Untuk medapatkan pencocokan pada pada seismogram di stasiun CTAO, gelombang Rayleigh dikoreksi negatif pada mantel atas dan koreksi negatif pada lapisanlapisan di bawahnya hingga CMB untuk mendapatkan pencocokan pada ScS dan sScS dan juga $\mathrm{ScS}_{2}$ dan $\mathrm{sScS}_{2}$.

Anomali negatif ke arah selatan dan barat daya dan positif ke arah tenggara tidak berkaitan dengan aktifitas termodinamika, karena tidak ada aktifitas kegunung-apian dalam struktur bumi dimana gelombang seismik menjalar dari hiposenter ke stasiun-stasiun observasi. Anomali ini disebabkan semata oleh perubahan sifat kimia dalam batuan-batuan penyusun lapisan mantel di bawah OJP. 


\section{$4 \quad$ Kesimpulan}

Riset ini menyelidiki struktur kecepatan gelombang $\mathrm{S}$ di bawah OJP melalui perbandingan seismogram dalam domain waktu dan tiga komponen, dimana model bumi yang digunakan bersifat anisotrop vertikal di mantel atas. Pengukuran selisih waktu tiba melalui perbandingan waveform. Selisih waktu tiba negatif hanya dijumpai pada tiga stasiun, yaitu HNR, CTAO dan SNZO, sementara stasiun yang lain, MSVF menunjukkan bahwa fase gelombang sintetik dari PREMAN terlambat dibanding fase gelombang terukur.

Hasil riset dengan bentuk gelombang dalam tiga komponen menunjukkan model kecepatan yang berbeda dengan model hasil-hasil riset lainnya. Anomali kecepatan gelombang S dijumpai pada lapisan-lapisan mantel bumi yang lebih dalam dari $300 \mathrm{~km}$ untuk mendapatkan pencocokan pada gelombanggelombang dalam dan juga gelombang dalam yang dipantulkan oleh permukaan bumi.

\section{Daftar Pustaka}

[1] Gomer, B.M. \& Okal, E.A., Multiple-ScS Probing of the Ontong-Java Plateau, Phys. of the Earth and Planet Int., 138, 317-331, 2003.

[2] Dziewonski, A.M. \& Anderson, D.L., Preliminary Reference Earth Model, Phys. of the Earth and Planet Int., 25, 297-356, 1981.

[3] Richardson, W.P., Okal, E.A., Van der Lee, S., Rayleigh-Wave Tomography of the Ontong-Java Plateau, Phys. Of the Earth and Planet Int., 118, 29-51, 2000.

[4] Talandier, J., Okal, E.A., On the Mechanism of Conversion of Seismic Waves to and from $T$ Waves in the Vicinity of Island Shores, Bull. Seismol. Soc. Am., 88, 621-632, 1998.

[5] Bott, M.H.P., Gunnarsson, K., Crustal Structure of the Iceland-FcerS Ridge, J. Geophys. 47, 221-227, 1980.

[6] Woods, M.T., Okal, E.A., The Structure of the Nazca Ridge and Salay Gomez Seamount Chain from the Dispersion of Rayleigh Waves, Geophys. J. Int. 117, 205-222, 1994.

[7] Evans, J.R. \& Sacks, I.S., Deep Structure of the Iceland Plateau. J. Geophys. Res. 84, 6859-6866, 1979.

[8] Takeuchi, H. \& Saito, M., Seismic Surface Waves in Methods in Computational Physics, Academic Press, 1972.

[9] Dalkolmo, J., Synthetische Seismogramme Fuer Eine Sphaerisch Symmetrische, Nicht Rotierende Erde Durch Direkte Berechnung der Greenschen Funktion, Diplomarbeit, Inst. fuer Geophys., Uni. Stuttgart, 1993. 
[10] Okal, E.A. \& Anderson, D.L., A Study of Lateral Inhomogeneities in the Upper Mantle by Multiple ScS Travel-Time Residuals, Geophys. Res. Lett., 2, 313-316, 1975.

[11] Sipkin, S.A. \& Jordan, T.H., Lateral Heterogeneity of the Upper Mantle Determined from the Travel Times of Multiple $S c S$, J. Geophys. Res. 81, 6307-6320, 1976.

[12] Friederich, W. \& Dalkolmo, J., Complete Synthetic Seismograms for A Spherical-Ly Symmetric Earth by A Numerical Computation of the Green's Function in the Frequency Domain, Geophys. J. Int., 122, 537 550, 1995.

[13] Bagus, J.S., Moeglichkeiten Und Grenzen Der Modellierung Vollstaendiger Lang-Periodischer Seismogramme, Doktorarbeit, Berichte Nr. 12, Inst. fuer Geophysik, Uni. Stuttgart, 1999.

[14] Dziewonski, A.M., Ekström, G., Salganik, M.P., Centroid Moment Tensor Solutions for April-June 1996, Phys. of the Earth and Planet Int., 102, 11-20, 1997. 